\title{
ANALISA KADAR AIR DAN UJI ORGANOLEPTIK IKAN KAKAP MERAH (Lutjanus sp.) DAN IKAN LAYANG (Decapterus sp.) SEGAR YANG DIJUAL DI PASAR PINASUNGKULAN MANADO
}

\author{
Manuela Mathelda Reba, Daisy M. Makapedua, dan Rastuti W. Paparang \\ Fakultas Perikanan dan Ilmu Kelautan, Universitas Sam Ratulangi, Manado, Sulawesi Utara.
}

\begin{abstract}
ABSTRAK
Ikan Kakap Merah (Lutjanus sp) dikenal dengan nama Ikan Merah dan ikan Layang (Decapterus sp) yang dikenal dengan nama Malalugis di Sulawesi Utara termasuk jenis ikan yang bernilai ekonomis tinggi dan biasanya dipasarkan dalam bentuk segar. Penelitian ini bertujuan untuk menganalisa kadar air dan uji organoleptik ikan Kakap Merah dan ikan Layang segar yang dipasarkan di pasar Pinasungkulan Manado. Metode penelitian yang digunakan adalah metode eksperimental, yaitu suatu penelitian yang dilakukan untuk mengetahui atau mengungkapkan keterangan suatu fakta secara terperinci dan sistematis. Hasil penelitian menunjukkan bahwa kadar air ikan Kakap Merah adalah $73,70 \%$, sedangkan kadar air ikan Layang adalah 73,15\%. Hasil uji organoleptik pada beberapa komponen seperti mata ikan Kakap Merah adalah 8,10, mata ikan Layang 7,77. Pada insang ikan Kakap Merah 7,69 dan insang ikan Layang 8,00. Pada daging dan perut ikan Kakap Merah 7,70, pada daging dan perut ikan Layang 7,85. Nilai bau ikan Kakap Merah yaitu 8,12 dan nilai bau ikan Layang yaitu 8,07. Nilai tekstur ikan Kakap Merah adalah 7,70 dan nilai tekstur ikan Layang yaitu 7,80. Berdasarkan hasil analisa kadar air dan uji organoleptik ikan Kakap Merah dan ikan Layang yang dijual di pasar Pinasungkulan Manado menunjukkan dalam keadaan yang masih baik yaitu tergolong segar.
\end{abstract}

Kata kunci: Kakap Merah (Lutjanus sp), Layang (Decapterus sp), kadar air, organoleptik.

\section{PENDAHULUAN}

Dalam pembangunan ekonomi Indonesia, perikanan adalah kegiatan pemanfaatan sumber daya alam yang di arahkan dengan sasaran utama pencukupan kebutuhan pangan, peningkatan kesempatan kerja, peningkatan pendapatan devisa dan pemeliharaan lingkungan yang lestari (Harahap, 2011). Perikanan adalah suatu kegiatan ekonomi yaitu usaha manusia memanfaatkan sumber daya alam dengan cara menerapkan kaidah teknologi secara ekonomis untuk mencapai kesejahteraan manusia melalui produksi hasil perikanan. Menurut 1lyas (1983) bahwa kegiatan terbesar dari hasil perikanan disalurkan dalam bentuk pemasaran segar terutama sebagai ikan basah baik yang didinginkan atau tanpa pendinginan.

Ikan merupakan komoditi yang mudah membusuk sehingga sangat sulit untuk mempertahankan kesegaran ikan sampai ke tangan konsumen (Afrianto dan Liviawaty 1989). Prinsip penanganan ikan segar adalah mempertahankan kesegaran ikan dengan cara memperlakukan ikan dengan hati-hati, segera menurunkan suhu atau mendinginkan ikan sehingga mencapai suhu $0^{\circ} \mathrm{C}$ serta selalu memperhatikan waktu dan kecepatan bekerja selama rantai penanganan (llyas, 1983). Untuk itu perlu dilakukan penelitian untuk mempelajari cara penanganan hasil perikanan yang cepat dengan metode yang tepat agar tingkat kesegaran ikan dapat terus dipertahankan sampai ke tangan konsumen.

Penelitian ini bertujuan untuk menganalisa kadar air dan uji organoleptik dari jenis ikan demersal yaitu ikan Kakap Merah (Lutjanus sp) dan jenis ikan pelagis yaitu ikan Layang (Decapterus sp) yang dijual di pasar Pinasungkulan Manado.

\section{METODOLOGI PENELITIAN}

Metode yang digunakan dalam penelitian ini merupakan metode eksperimental dimana suatu penelitian yang dilakukan dengan cara mengubah suatu keadaan untuk melihat kejadian yang timbul akibat dari perubahan itu (Mantjoro dkk., 1981).

\section{Bahan dan Alat}

Bahan yang digunakan dalam penelitian ini adalah jenis ikan demersal yaitu ikan Kakap 
Merah dengan ukuran panjang per ekor berkisar $30-50 \mathrm{~cm}$ dan berat per ekor 825-1000 gram dan jenis ikan pelagis yaitu ikan Layang dengan ukuran panjang per ekor berkisar 18-25 $\mathrm{cm}$ dan berat per ekor 90-200 gram. Jumlah ikan yang digunakan adalah 5 ekor ikan Kakap Merah dan 12 ekor ikan Layang. Bahan yang digunakan untuk penanganan ikan sejak dibeli dan dibawa ke Laboratorium Penanganan dan Pengolahan Hasil Perikanan dengan menggunakan hancuran es kemudian disimpan dalam cool box.

Peralatan yang digunakan untuk analisa kadar air: cawan porselin, tang penjepit, desikator, timbangan analitik, dan oven. Sedangkan alat untuk pengujian organoleptik antara lain: piring plastik, talenan, pisau, timbangan, kertas tissue, lembar penilaian (score sheet) dan pulpen.

Penelitian ini dilaksanakan di Laboratorium Penanganan dan Pengolahan Hasil Perikanan, Fakultas Perikanan dan Ilmu Kelautan Universitas Sam Ratulangi Manado. Waktu pelaksanaan penelitian selama bulan Oktober-November 2014.

\section{Tata Laksana Penelitian}

Pengamatan dan pengambilan sampling I dilakukan pada hari Kamis, 6 November 2014 pukul 06:00 WITA di pasar Pinasungkulan Manado. Membeli ikan segar yang baru didaratkan yaitu 5 ekor ikan kakap merah dan 12 ekor ikan layang. Ikan tersebut diletakkan dalam cool box yang sudah ditaruh hancuran es, kemudian segera dibawa ke Laboratorium Penanganan dan Pengolahan Hasil Perikanan dan dilakukan analisa kadar air dan uji organoleptik. Perbandingan Ikan dan es adalah $8 \mathrm{~kg}$ ikan : $16 \mathrm{~kg}$ es batu. Uji organoleptik dapat dilakukan sekitar pukul 08:00 WITA.

Pengamatan dan pengambilan sampling II dilakukan pada hari Jumat, 7 November 2014 pukul 06:00 WITA di pasar Pinasungkulan Manado. Membeli ikan segar yang baru didaratkan yaitu 5 ekor ikan kakap merah dan 12 ekor ikan layang. Ikan tersebut diletakkan dalam cool box yang sudah ditaruh hancuran es, kemudian segera dibawa ke Laboratorium Penanganan dan Pengolahan Hasil Perikanan dan dilakukan analisa kadar air dan uji organoleptik. Perbandingan Ikan dan es adalah $8 \mathrm{~kg}$ ikan : $16 \mathrm{~kg}$ es batu. Uji organoleptik dapat dilakukan sekitar pukul 08:00 WITA. Pengambilan sampel telah dilakukan ulangan sebanyak 2 kali.

\section{Analisa Kadar Air (AOAC 1995)}

Analisa kadar air dengan menggunakan oven. Kadar air dihitung sebagai persen berat, artinya berapa gram berat contoh dengan yang selisih berat dari contoh yang belum diuapkan dengan contoh yang telah diuapkan (dikeringkan). Jadi kadar air dapat diperoleh dengan menghitung kehilangan berat contoh yang dipanaskan. Urutan kerjanya sebagai berikut:

1. Cawan porselin dengan penutupnya dibersihkan dan dikeringkan dalam oven pada suhu $105^{\circ} \mathrm{C}-110^{\circ} \mathrm{C}$ selama 1 jam. Kemudian didinginkan dalam desikator selama 30 menit dan ditimbang beratnya (A gram).

2. Sampel ditimbang sebanyak 2 gram dan ditaruh dalam cawan porselin yang telah diketahui beratnya (B gram). Sampai dalam porselin ini kemudian dikeringkan dalam oven pada suhu $105^{\circ} \mathrm{C}-110^{\circ} \mathrm{C}$ sampel konstan selama 24 jam, selanjutnya didinginkan dalam desikator selama 30 menit dan ditimbang (C gram).

3. Penimbangan ini diulangi sampai diperoleh berat yang konstan. Adapun persentase kadar air yang dapat dihitung sebagai berikut:

$$
\begin{aligned}
& \text { Kadar air }=\frac{\mathrm{B}-\mathrm{C}}{\mathrm{B}-\mathrm{A}} \text { X } 100 \% \\
& \text { Dimana: } \\
& \mathrm{A}=\text { Berat kering cawan (gr) } \\
& \mathrm{B}=\text { Berat kering cawan dan sampel awal (gr) } \\
& \mathrm{C}=\text { Berat kering cawan dan sampel setelah } \\
& \quad \text { dikeringkan (gr) }
\end{aligned}
$$

\section{Uji Organoleptik (SNI 2006)}

Uji organoleptik adalah cara penilaian dengan hanya menggunakan indra manusia (sensorik). Penilaian organoleptik merupakan cara yang paling banyak dilakukan dalam menentukan tanda-tanda kesegaran ikan karena lebih cepat dikerjakan, tidak memerlukan banyak peralatan serta murah (Hadiwiyoto, 1993). Uji organoleptik dapat dilakukan dengan menggunakan lembar penilaian (score sheet) yang telah ditetapkan oleh Badan Standarisasi Nasional dengan SNI 01-2346-2006, meliputi penampakan luar, kelenturan daging (konsistensi), keadaan mata, daging, dan perut serta warna insang.

\section{Analisa Data}

Hasil pengamatan bersifat kuantitatif yang diperoleh dari data hasil pengamatan dan dilakukan perhitungan dengan menggunakan 
nilai rata-rata yang kemudian dari hasil tersebut disajikan dalam bentuk table dan histogram.

\section{HASIL DAN PEMBAHASAN}

\section{Analisa Kadar Air Ikan Kakap Merah dan Ikan Layang Segar}

Pada Tabel 1 menunjukkan bahwa, nilai rata-rata kadar air ikan kakap merah yaitu sebesar $73,70 \%$ dan nilai rata-rata kadar air ikan layang yaitu sebesar 73,15\%. Histogram nilai rata-rata persentase kadar air ikan Kakap Merah dan ikan Layang dapat dilihat pada Gambar 1.

Dari histogram di atas sangat jelas menunjukkan bahwa kadar air ikan Kakap Merah (73,70\%) lebih tinggi dibandingkan dengan kadar air ikan Layang (73,15\%). Menurut Kristantina (2013) bahwa kadar air ikan Kakap Merah segar yaitu 79,31\% sedangkan Burhanudin $d k k$., (1983) menyatakan bahwa kadar air ikan Layang yaitu 76,7\%. Hasil penelitian ini menyimpulkan bahwa kadar air dari kedua jenis ikan yaitu ikan Kakap Merah (ikan demersal) dan ikan Layang (ikan pelagis) tidak menunjukkan perbedaan yang signifikan.

\section{Uji Organoleptik Ikan Kakap Merah dan Ikan Layang Segar}

Pada Tabel 2 terlihat bahwa ikan Layang yang dibeli di pasar Pinasungkulan pada sampling I memiliki tingkat kesegaran mutu yang lebih tinggi dibandingkan dengan ikan Kakap Merah pada sampling I, hal ini disebabkan karena ikan Layang yang dijual pada saat itu adalah ikan yang baru saja didaratkan dari Tempat Pelelangan Ikan (TPI) pasar Bersehati kemudian diangkut ke pasar Pinasungkulan, sedangkan ikan Kakap Merah yang dijual pada saat itu adalah kelebihan ikan dari penjualan ikan di hari sebelumnya.

Tabel 1. Data hasil analisa kadar air ikan Kakap Merah (Lutjanus sp) dan ikan Layang (Decapterus sp) segar.

\begin{tabular}{lccr}
\hline \multicolumn{1}{c}{ Jenis } & \multicolumn{2}{c}{ Sampling Kadar Air } & \multicolumn{1}{c}{ Nilai } \\
Ikan & I & II & rata-rata \\
\hline Kakap Merah & 73,10 & 74,30 & $73,70 \%$ \\
Layang & 73,39 & 72,90 & $73,15 \%$ \\
\hline
\end{tabular}

Ikan Kakap Merah yang dibeli di pasar Pinasungkulan pada sampling II memiliki tingkat kesegaran yang lebih tinggi dibandingkan dengan ikan Layang pada sampling II, hal ini disebabkan karena ikan Kakap Merah yang dijual pada saat itu adalah ikan yang baru saja didaratkan dari TPI pasar Bersehati kemudian diangkut ke pasar Pinasungkulan, sedangkan ikan Layang yang dijual pada saat itu adalah kelebihan ikan dari penjualan di hari sebelumnya.

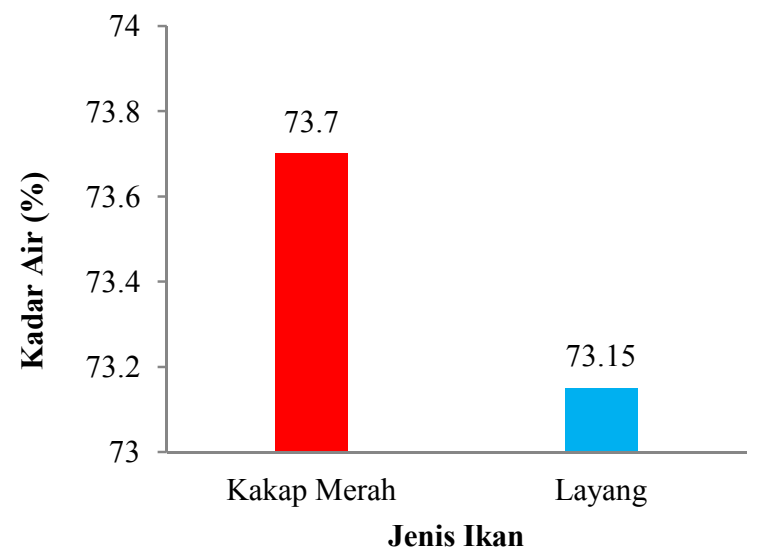

Gambar 1. Histogram kadar air ikan Kakap Merah (Lutjanus sp) dan ikan Layang (Decapterus sp) segar.

Tabel 2. Data hasil uji organoleptik ikan Kakap Merah (Lutjanus sp) dan ikan Layang (Decapterus sp) segar.

\begin{tabular}{|c|c|c|c|c|}
\hline \multirow[b]{2}{*}{$\begin{array}{l}\text { Jenis } \\
\text { Ikan }\end{array}$} & \multicolumn{4}{|c|}{ Uji Organoleptik } \\
\hline & Komponen & $\begin{array}{c}\text { Sampling } \\
\text { I }\end{array}$ & $\begin{array}{c}\text { Sampling } \\
\text { II }\end{array}$ & $\overline{\mathbf{X}}$ \\
\hline \multirow{6}{*}{$\begin{array}{l}\text { Kakap } \\
\text { Merah }\end{array}$} & Mata & 7,75 & 8,45 & 8,10 \\
\hline & Insang & 7,6 & 7,79 & 7.69 \\
\hline & Daging dan & 7,55 & 7,85 & 7,70 \\
\hline & Perut & & & \\
\hline & Bau & 7,9 & 8,35 & 8,12 \\
\hline & Tekstur & 7,7 & 7,7 & 7,70 \\
\hline \multirow{5}{*}{ Layang } & Mata & 8,1 & 7,45 & 7,77 \\
\hline & Insang & 8,25 & 7,75 & 8,00 \\
\hline & $\begin{array}{l}\text { Daging dan } \\
\text { Perut }\end{array}$ & 8,05 & 7,65 & 7,85 \\
\hline & $\mathrm{Bau}$ & 8,35 & 7,8 & 8,07 \\
\hline & Tekstur & 8,2 & 7,4 & 7,80 \\
\hline
\end{tabular}

Dari hasil uji organoleptik pada 20 panelis yang semi terlatih masing-masing mempunyai penilaian yang berbeda-beda dengan organ tubuh pada ikan Kakap Merah dan ikan Layang. Hasil uji organoleptik pada komponen mata, insang, daging dan perut, bau, tekstur dapat dilihat pada Gambar 2.

Hasil Uji organoleptik pada 20 panelis dari masing-masing organ tubuh pada komponen mata, insang, daging dan perut, bau dan tekstur mempunyai penilaian yang berbedabeda. Kedua jenis ikan tersebut yaitu ikan Kakap Merah dan ikan Layang memiliki nilai uji organoleptik yang tinggi yaitu diatas 7. Ikan Kakap Merah mempunyai nilai organoleptik 
yang lebih tinggi dari ikan Layang. Untuk membandingkan hasil penelitian dengan standar nilai organoleptik ikan segar di atas 7 , dapat di simpulkan bahwa pada jam 06:00 WITA ikan masih dalam keadaan segar dan memenuhi Standar Nasional Indonesia (SNI).

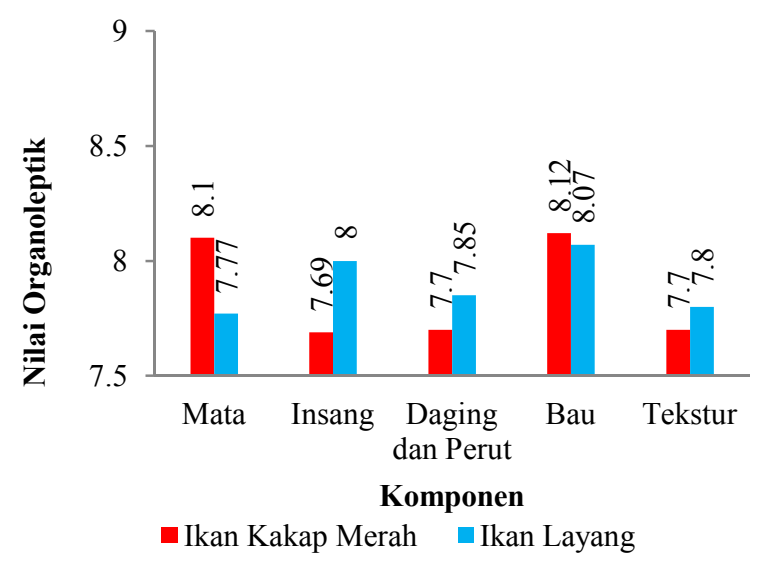

Gambar 2. Histogram uji organoleptik ikan Kakap Merah (Lutjanus sp) dan ikan Layang (Decapterus sp) segar.

\section{KESIMPULAN}

Kadar air ikan Kakap Merah adalah $73,70 \%$ dan nilai kadar air pada ikan Layang adalah 73,15\%. Hasil uji organoleptik ikan Kakap Merah dengan nilai rata-rata adalah 7,78,12 dan ikan Layang dengan nilai adalah 7,69-
8,07. Hasil analisa kadar air dan uji organoleptik ikan Kakap Merah dan ikan Layang yang dijual di pasar Pinasungkulan Manado menunjukkan kedua jenis ikan ini dalam keadaan yang masih baik yaitu tergolong segar.

\section{DAFTAR PUSTAKA}

Afrianto, E dan Liviawaty, E, 1989. Pengawetan Dan Pengolahan Ikan. Kanisius, Yogyakarta.

AOAC, 1995. Official Methods of Analysis of the Association Of Analytical Chemists. Washington.

Burhanuddin, S.,A., Djamali, S., Mortosuwejo dan Moeljanto, 1983. Evaluasi dan Usaha Pengenalan Sumber Daya Ikan Layang (Decapterus sp). Proyek Studi Potensi Sumber Daya Hayati Ikan. Lembaga Oseanologi Nasional LIPI, Jakarta.

Harahap, $2011 \quad$ Kakap Merah. http://fishyforum.blogspot.com/2008/02/ikan-kakapmerah-Lutjanus.sp-circumpectus.html

IIyas, S. 1983. Teknologi Refrigerasi Hasil Perikanan. Jilid I. Teknik Pendinginan Ikan. Jakarta.

Kristantina, Widyana, Ayu. 2013. Komposisi Asam Lemak. Fakultas Perikanan, Institut Pertanian Bogor, Bogor.

Mantjoro, E. 1981. Metodologi Penelitian. Fakultas Perikanan Universitas Sam Ratulangi. Manado.

Saanin, H. 1984. Taksonomi dan Kunci Identifikasi Ikan. Penerbit Bina Cipta, Jakarta. 